\title{
Ground Water Pollution near the Industrial Area at Jalgaon District, Maharashtra State
}

\author{
${ }^{1}$ Landge M. G ${ }^{*}{ }^{2}$ Badade S. S, ${ }^{3}$ Kendre B. V \\ ${ }^{1}$ Department of Chemistry, Government College of Engineering, Jalgaon, MS, India \\ ${ }^{2}$ Department of Chemistry, Dr. Babasaheb Ambedkar Marathwada University, MS, India \\ ${ }^{3}$ P.G. Department of Chemistry, Vaidyanath College, Parli-Vaijnath, MS, India \\ mglandge@rediffmail.com
}

\begin{abstract}
Abstact: Investigation of physico - chemical constituents of well water near the industrial area at M.I.D.C. Jalgaon was done. During the analysis it was observed that well water is polluted due to percolation seepage of industrial sewages and making the water unsuitable for domestic purpose in rainy season and in winter the degree of pollution is less but it is high in summer.
\end{abstract}

Keywords: Physico-chemical constituents,well water, analysis,pollution, sewage, domestic, season etc.

\section{INTRODUCTION}

Due to waste increase in the industries and improper management of effluent, pollution has become devastating problem in the development of the near by villages more over negligence towards the treatment of the effluent. This results the surface water pollution as well as the ground water pollution. In the present work the physico-chemical analysis was done to study the pollution of water. However the independent variable, that contribute the pollution can be measured combined resultant can quantitatively expressed. Statistical method such as principal component analysis and factor analysis are the best methods in this context. As a case study the parameters responsible for pollution such as BOD, COD, pH, DO, alkalinity, Total bacteria, E-coli, Chlorides, Calcium, Magnesium, Total hardness, Temporary hardness, Permanent hardness, Total dissolved solids, turbidity etc, have been estimated in well water and tube wells near the industrial area at M.I.D.C Jalgaon district.

\section{Importance And Purpose of Chemical Analysis}

The chemical analysis for the well water and tube wells near industrial area has become prominent issue of every city in Maharashtra and India. The physical examination attributes the color clarity on and test have became of greater importance in classifying the portable quality of water. This well water was first used for domestic as well as agricultural purpose since past 5- 6 years as the industrial area has developed near by this wells, due to percolation seepage of the industrial effluents the total near by well water is polluted to such an extent that it is unsuitable for domestic purpose. It is observed that before rainy season mostly in the month of March, April and May the water has been developed reddish - brown color. In summer as the level of well water is decreased the concentration of the dissolved effluents is increased and thus it becomes reddish-brown color. This well is near the industrial area from where the industrial effluents percolates seepage could enter into the wells. After the rains as level of rain water increases moreover seepage could not.

\section{MATERial AND MethodS}

In every month of the $1^{\text {st }}$ date of the time in between 10.00 a.m. to 12.00 a.m., about one liter of water sample from the well was taken in previously cleaned dried polythene jar or bislleri bottle with necessary precaution and brought to the laboratory for analysis. The samples were analyzed for the average values of the various physic-chemical parameters as per standard methods. All the chemicals used as such without further purification for the reagent preparation were of $\mathrm{BDH}, \mathrm{SD}$ fine chemicals and Analar grade.

Most of the salts and variety of organic substances (except lipids ), are soluble in water. Thus, a water sample either from surface, ground or marine sources, contains appreciable quantity of dissolved 


\section{Landge M. G et al}

solids, ${ }^{1}$ normally confer a degree of hardness of it. Dissolved oxygen (DO ) is one of the most important parameter of water quality directly affecting survival and distribution of flora and fauna in an ecosystem. The two main sources of DO are diffusion and photosynthesis. Natural water normally has a low chloride contents compared to bicarbonates and sulfates. High chlorides level indicates pollution from domestic sewage and industrial effluents. Though chloride level as high as $250 \mathrm{mg} / \mathrm{lit}$. is safe for human consumption, a level above this imparts a salty taste to the potable water. Hardness to water is normally imparted by alkaline earth metallic cations, mainly calcium and magnesium present in it. Calcium and magnesium is the major cations present in natural waters, its main source being leaching of rocks in the catchment. Ca concentration restricts water use, while it is an important component in the exoskeleton of Arthropods and Shells in Molluscs. Mg is the vital component of chlorophyll. Very high concentration of Mg imparts an unpleasant taste to the potable water.

Table1. Standards for quality of water

\begin{tabular}{|c|l|l|}
\hline Sr. No. & \multicolumn{1}{|c|}{ Parameter (s) } & \\
\hline 1 & pH & $6.5-8.5$ \\
\hline 2 & D.O. & 3.00 \\
\hline 3 & Total bacteria & ---- \\
\hline 4 & E- Coli & ---- \\
\hline 5 & BOD & $<4$ ppm \\
\hline 6 & Total hardness & 300 \\
\hline 7 & Permanent hardness & ---- \\
\hline 8 & Alkalinity & 300 \\
\hline 9 & Chlorides & 250 \\
\hline 10 & Flourides & $<1 \mathrm{ppm}$ \\
\hline 11 & Turbidity & $10 \mathrm{NTU}$ \\
\hline 12 & Total solids & 500 \\
\hline 13 & TDS & 2100 \\
\hline 14 & TSS & ----- \\
\hline 15 & Calcium & $75 \mathrm{ppm}$ \\
\hline 16 & Magnesium & $30 \mathrm{ppm}$ \\
\hline 17 & Sulfate & 150 \\
\hline
\end{tabular}

Table2. Yearly analysis of water quality using physico-chemical parameters of well waters near M.I.D.C. Jalgaon

\begin{tabular}{|l|l|l|l|l|}
\hline \multicolumn{1}{|c|}{ Months } & \multicolumn{1}{c|}{ Temp $^{\mathbf{0}} \mathbf{c}$} & \multicolumn{1}{c|}{ Turbidity NTS } & \multicolumn{1}{c|}{ TDS mg/l } & pH \\
\hline Jan & 22.50 & 10.45 & 220.50 & 8.05 \\
\hline Feb & 24.00 & 11.00 & 214.00 & 8.10 \\
\hline Mar & 26.00 & 14.00 & 218.00 & 8.00 \\
\hline Apr & 24.50 & 9.00 & 160.00 & 8.20 \\
\hline May & 26.50 & 8.50 & 130.00 & 7.50 \\
\hline Jun & 24.50 & 6.00 & 250.50 & 7.10 \\
\hline July & 23.50 & 7.00 & 235.00 & 7.00 \\
\hline Aug & 23.00 & 6.50 & 150.50 & 7.10 \\
\hline Sept & 24.00 & 4.50 & 135.00 & 6.80 \\
\hline Oct & 25.00 & 4.00 & 145.00 & 7.90 \\
\hline Nov & 23.00 & 6.50 & 205.00 & 7.25 \\
\hline Dec & 22.00 & 8.00 & 180.50 & 7.80 \\
\hline
\end{tabular}

Table3. The physico-chemical parameters of well waters near M.I.D.C. Industrial area Jalgaon

\begin{tabular}{|l|l|c|c|}
\hline Sr No. & Parameters & Observed values- min & Observed value - max \\
\hline 1 & $\mathrm{pH}$ & 7.0 & 8.20 \\
\hline 2 & BOD & 1.5 & 2.80 \\
\hline 3 & COD & 13.0 & 20.00 \\
\hline 4 & Total hardness & 404.00 & 482.00 \\
\hline 5 & Permanent hardness & 128.00 & 212.00 \\
\hline 6 & Alkalinity & 257.00 & 297.00 \\
\hline 7 & Chloride & 89.00 & 98.00 \\
\hline 8 & Flouride & 0.260 & 0.286 \\
\hline 9 & Turbidity & 2.3 & 3.5 \\
\hline & & 4.0 & 14.00 \\
\hline 10 & Total solids & 667.00 & 745.00 \\
\hline
\end{tabular}


Ground Water Pollution near the Industrial Area at Jalgaon District, Maharashtra State

\begin{tabular}{|l|l|l|l|}
\hline \hline 11 & TDS & 651.00 & 729.00 \\
\hline & TDS & 130.00 & 251.00 \\
\hline 12 & TSS & 15.00 & 40.00 \\
\hline 13 & Calcium & 71.90 & 74.20 \\
\hline 14 & Sulfate & 12.90 & 15.80 \\
\hline 15 & Magnesium & 71.00 & 75.80 \\
\hline
\end{tabular}

Table4. The physico-chemical characteristics of the tube wells sample near M.I.D.C. Jalgaon

\begin{tabular}{|l|l|l|}
\hline \multicolumn{1}{|c|}{ Sr. No. } & \multicolumn{1}{c|}{ In $\mathbf{~ m g}$ / lit } \\
\hline 1 & $\mathrm{pH}$ & 7.10 to 8.20 \\
\hline 2 & Color & Colorless to reddish-brown \\
\hline 3 & BOD & 2.8 \\
\hline 4 & COD & 20.00 \\
\hline 5 & TDS & 600.00 \\
\hline 6 & Permanent hardness & 180.00 \\
\hline 7 & Alkalinity & 222.50 \\
\hline 8 & Chloride & 90.00 \\
\hline 9 & Sulfate & 41.00 \\
\hline 10 & Nitrate & 0.08 \\
\hline 11 & Ammonia & 0.18 \\
\hline 12 & Nickel & 0.18 \\
\hline 13 & Total bacteria & 900.00 \\
\hline 14 & E-coli & 600.00 \\
\hline 15 & Flouride & 0.27 \\
\hline 16 & Turbidity & 3.5 \\
\hline 17 & TSS & 30.00 \\
\hline 18 & Calcium & 72.00 \\
\hline 19 & Magnesium & 71.00 \\
\hline
\end{tabular}

\section{RESUlT AND DISCUSSION}

The results of the physico-chemical parameters of the well waters near the industrial area of M.I.D.C Jalgaon are presented as in the table.2,3and 4.

Throughout the year the total bacteria are greater than 1600. Except Jan. and Nov., the E-coli are also more than 500 to 700, the BOD is min 1.5 in Jan and 2.8 in Mar., COD is min. 13 and Max. 20 Jan and Aug. The total hardness min. 404 in Oct. and Max 482 in Apr. The permanent hardness min. 128 in Apr. and Max. 212 in Jan. Alkalinity is min. 257 in Oct. and max. 297 in June,Chlorides min. 89 in Mar. and max. 98 in May, Flouride min. 0.260 in Nov. and max. 0.286 in May and June. Turbidity min. 2.3 in July and max. 3.5 in Dec. Feb and Mar. total solids min. 667 in Aug and max. 745 in Oct. and Nov., TDS min. 651 in Aug and max. 729 in Jan., TSS min. 15 in July and max. 40 in July, Calcium min. 71.9 in Nov. and max. 74.2 in Mar. Magnesium min. 71 in Feb and max. 75.8 in June, Sulfate min. 12.90 in Nov. and max. 15,80 in June. The turbidity of water fluctuates from 4 to 14 NTU. The maximum value 14 was recorded in the month of March, probably due to decrease in water level, presence of particulate and also due to human activities ${ }^{2}$, on other hand the minimum value $4 \mathrm{NTU}$ is in the month of October. Total dissolved solids changes from 130 to $251 \mathrm{mg} / \mathrm{l}$, the maximum value $250.50 \mathrm{mg} / \mathrm{l}$ was recorded in the month of June. Possibly, it may due to high rain fall and minimum value $130 \mathrm{mg} / \mathrm{l}$ in the month of May. The $\mathrm{pH}$ value ranges from 7 to 8.20 . The maximum $\mathrm{pH}$ value 8.20 was observed in the month of April and minimum 7 in the month of October. The different factor ${ }^{3}$ such as humidity, temperature etc bring changes in the $\mathrm{pH}$ of water.

The water under study is from dry zone, there is a rapid increase in temperature after the month of January. April to May is the hottest months. The climate of the year is divided into four season like hot season from March to May, South-west monsoon from June to September, Post-monsoon from October to November, winter from December to February with an average wind speed 4.50 to 5.50 $\mathrm{km} / \mathrm{hrs}$. The maximum and minimum wind velocity ${ }^{4}$ in the tank area was observed in the month of July to May are 7.90 to $0.1 \mathrm{~km} / \mathrm{hrs}$ respectively.

\section{CONCLUSION}

Due to the vast industrialization and improper waste management, pollutants are increased in surface and sub surface water in the well near the industrial area at M.I.D.C. Jalgaon. The wells at a distance of approximate $20 \mathrm{Km}$ from the industrial area did not show an increase in values of water parameters. These well water is suitable for domestic purpose. This clearly shows that the quality of 
water in wells near the industrial area of M.I.D.C, Jalgaon is adversely effected due to the percolation seepage of effluents.

Comparison of our results with the standards prescribed for domestic supply, it is observed that the nature of well water near industrial area of Jalgaon deviate from the limits prescribed hence, well water has to be treated to confirm for domestic as well as agricultural use.

These well waters deviate very much particularly with regard to total bacteria, E-coli, hardness, alkalinity, total solids etc, hence special treatment must be given to make it suitable for any particular industry before it is being diverted to that end.

\section{ACKNOWLEDGEMENT}

The authors are thankful to Dr. R.K. Ippar Principal, Vaidyanath Arts, Science and Commerce college, Parli-vaijnath, Dist-Beed for encouragement.

\section{REFERENCES}

[1] Lysimetric approach for ground water pollution control from pulp and paper mill effluent using different soil textures, A. Kumar and J.P. Rai., Indian journal of scientific and Industrial Research., vol. 63, pp 429-438, (2004).

[2] Evolution process of ground water quality in an urban area., Sef.Laye Alfa- Sika Mande Honghan Chen., African journal of agricultural research ., vol. 6(6), pp- 1295-1302,(2012).

[3] Physico-chemical characteristics of ground water in old port Harcourt township, Eastern Niger Delta ., F.I. Fashola and A.C.Tse ., International journal of physical sciences ., vol. 1(3), pp- 4755,(2013).

[4] Prediction of nitrate contamination trends of ground water in Al-Butana region of Sudan., Abdelmonem M. Abdellab and Nadia A. Yahia., Journal of environmental science and water resources., vol . 1(6), pp- 133-143, (2012).

[5] The impact of municipal Iandfill on surface and ground water quality in bulawayo, Zimbabwe., M.S. Magombeyi and R. Nyengera., Journal of environmental sciences and water resources., vol $1(10)$, pp- 251-258,(2012).

[6] Quality status of ground water resources in part of Birnin-gwari Schist Belt, North- Central Nigeria., H.O. Nwankwoala and K. O. Amede., Research journal of earth and planetary studies., vol. 2(10)

[7] , PP- 65-70,(2012).

[8] Statement of basis, Dutch cowboy dairy, groundwater quality discharge permit UGW 210006 , DWO- 2011-008134-doc. (June 2011).

[9] Final Appendix 6-B, Geology and groundwater, King County, dept of natural resources and parks wastewater treatment division, Bellevue, WA., (Nov.2003).

[10] Exploration, modeling and management of groundwater - dependent ecosystem in Karst- the sian Ka'an case study, Babi R. N. Gondwe, DTU Envi. Ph.D. thesis, Yucatan, Mexico., (March 2010).

[11] Groundwater dyanamics and global change., Association of Geo-environmentlists, international groundwater conference, university of Rajasthan- Jaipur., March 11-14, (2008).

\section{AUTHOR's BIOGRAPHY}

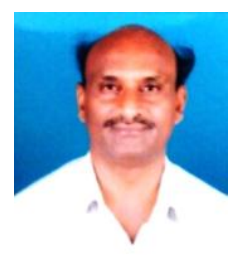

Dr. Mahadev Gangaram Landge, is presently working as Assistant Professor in Chemistry at Jawahar Education Society's Vaidyanath College, Parli-vaijnath Dist Beed of Maharashtra State. Previous to this he was worked as a Lecturer in chemistry at Government Engineering College, Jalgaon from 10-11-1998 to 25-10-2007 affiliated to North Maharashtra Unversity, Jalgaon. He has completed his research work under the guidance of Dr. B. R. Arbad, Professor, Dr BAMU, Aurangabad in year 1995. He is a recognized P. G. Teacher of Swami Ramanand Teerth Marathwada University, Nanded and research guide of Dr. Babasaheb Ambedkar Marathwada University, Aurangabad. Also he is BOS member of Autonomous Government College of Engineering, Jalgaon. He has published 18 research papers in International and National repute and participated in 20 conferences. He worked as a convener of one State level (Feb.-2010) and one National (Feb.-2015) conference at Vaidyanath college, Parli-vaijnath sanctioned by U.G.C. He completed one Minor research Project Sanctioned by U.G.C. New Delhi. His area of research is in physical chemistry and environmental chemistry. 